\title{
Hukum Islam dan Patronase dalam Penentuan 1 Ramadhan di Bungong Keumang
}

\author{
Cut Rahma Rizky, ${ }^{1}$ Agus Nurhadi ${ }^{2}$ \\ 1Pascasarjana Universitas Islam Negeri Ar-Raniry, Banda Aceh \\ e-mail: cutrahmar@gmail.com \\ ${ }^{2}$ Fakultas Syariah Universitas Islam Negeri Walisongo, Semarang \\ e-mail: agusnurhadi@walisongo.ac.id
}

\begin{abstract}
In 2017, people in Bungong Keumang village started fasting on Thursday, and they did not follow the government's decision to start fasting on Saturday. They prefer to follow the decisions of religious leaders who often overtake fasting, up to 2-3 days. This difference with the government has been going on for a long time, and almost every year has happened. This paper answers the question of why people in Bungong Keumang prefer to follow the decisions of religious leaders in starting Ramadhan fasting rather than following government decision? With in-depth interviews, answers were obtained that the choice of the community was more due to longstanding social patronage relations based on the exchange of values between religious leaders (patrons) and worshipers (clients) that are mutually beneficial to each other. The determination of 1 Ramadhan which is an area of Islamic law is an 'important arena' to strengthen patronage relations. However, at present the client's obedience to patrons is also shifting. The community is increasingly rational in making choices, access to information is also getting easier, and power relations are also decreasing, so the determination of 1 Ramadhan will become stronger into the area of astronomy and Islamic law.
\end{abstract}

[?

Pada tahun 2017, masyarakat Desa Bungong Keumang memulai puasa pada hari Kamis, dan tidak mengikuti keputusan Pemerintah yang memulai puasa pada hari Sabtu. Mereka lebih memilih mengikuti keputusan pemimpin agama yang sering mendahului puasa, hingga 2-3 hari. Perbedaan dengan Pemerintah ini telah berlangsung lama, dan hampir setiap tahun terjadi. Tulisan ini menjawab pertanyaan mengapa masyarakat di Bungong Keumang lebih memilih mengikuti pemimpin agama dalam memulai puasa Ramadhan daripada mengikuti ketentuan Pemerintah? Dengan wawancara mendalam diperoleh jawaban bahwa hal itu lebih disebabkan hubungan sosial patronase yang telah berlangsung lama yang berbasis pada pertukaran nilai antara pemimpin agama (patron) dan jama'ah (klien) yang saling menguntungkan satu sama lain. Penentuan 1 Ramadhan yang menjadi wilayah hukum Islam ini menjadi 'arena' penting untuk menguatkan hubungan patronase. Namun demikian, pada saat ini kepatuhan klien kepada patron juga mengalami pergeseran. Masyarakat semakin rasional dalam menentukan pilihan, akses kepada informasi juga semakin mudah, dan relasi kuasa juga menurun, maka penentuan 1 Ramadhan akan semakin kuat menjadi wilayah astronomi dan hukum Islam.

Keywords: hukum Islam; patronase; arena; Ramadhan 


\section{Pendahuluan}

Harian Rakyat Aceh di tahun 2017 memberitakan bahwa ribuan masyarakat Kabupaten Nagan Raya, mulai melaksanakan ibadah puasa Ramadhan 1438 Hijriah. Ketetapan berpuasa ini dua hari lebih cepat dibandingkan keputusan Pemerintah. Keputusan ini ditetapkan setelah tim dari Nagan Raya dan Aceh melakukan musyawarah. Mereka menyatakan belum melihat bulan pada Jumat (26/5) malam, bertepatan pada tanggal 29 bulan Sya'ban. Terjadinya perbedaan hingga 2 hari ini bukan hanya sekali, tetapi sudah sering terjadi. Masyarakat pengikut thariqat Habib Muda berpuasa lebih awal, awal Ramadhan jatuh pada hari Kamis (25/5), sedangkan puasa secara umum jatuh pada hari Sabtu (27/5)," kata Tgk Burhanuddin. ${ }^{1}$

Bagi masyarakat Bungong Keumang, berpuasa lebih awal ini bukanlah yang baru. Hampir setiap tahun mereka berpuasa lebih dulu dibandingkan masyarakat pada umumnya. Pencetus metode ini kakek dari Abu Habib Muda, ulama yang memperkenalkan Thariqat Syattariyah di Bungong Keumang. Beliau seorang mursyid thariqat yang dilahirkan di Desa Krueng Kulu Kecamatan Seunagan Aceh Barat. Beliau diakui sebagai seorang ulama, mursyid, dan seorang pejuang yang melawan penjajah.

Bungong Keumang, desa yang menjadi lokasi kajian ini, merupakan sebuah desa di Kecamatan Seunagan Timur, Nagan Raya. Di desa inilah awalnya Habib Muda bermukim dan mendakwahkan ajaran Islam kepada masyarakat luas. Desa Bungong Keumang terletak tidak jauh dari jalan nasional Banda Aceh-Singkil, sehingga lokasi ini mudah diakses oleh siapapun. Masyarakat Bungong Keumang sangat terbuka, menerima tamu ke kampung mereka, termasuk mereka yang ingin observasi dan mempelajari Thariqat Syattariyah. Mereka menerima dengan senang hati tamu dari luar yang ingin mengetahui keadaan masyarakat. Mereka tidak perlu pemeriksaan serius untuk mengetahui aktivitas sosial keagamaan di Bungong Keumang, karenanya mereka tidak eksklusif. $^{2}$

${ }^{1}$ Tim Liputan, "Warga Nagan Mulai Puasa," Harian Rakyat Aceh, accessed July 27, 2017, https://harianrakyataceh.com/2017/05/29/warga-nagan-mulai-puasa/.

${ }^{2}$ Sehat Ihsan, Abu Habib Muda Seuagan Republiken Sejati dari Aceh (Banda Aceh: Bandar Publishing, 2015), 7-8. 
Ada beberapa hal yang menarik dalam penentuan awal bulan oleh penduduk Bungong Keumang tersebut. Seperti yang dikatakan oleh Ketua MPU (Majelis Permusyawaratan Ulama) Nagan Raya, Tgk. Said Jamalul Hakim. ${ }^{3}$ "Mereka menentukan masuknya awal bulan dengan hitungan 5". Begitu pula yang dikatakan oleh Takmir Masjid Bungong Keumang Tgk. Marsyul Alam. "Sistem hisabiyah yang mereka praktikkan dalam bahasa Aceh disebut Hisab Hitungan Limeng". ${ }^{4}$ Dalam bahasa ilmu astronomi, metode yang digunakan Thariqat Syattariyah ini disebut dengan 'hisāb'urfi khumasi' - menghitung awal bulan Ramadhan tahun depan dengan cara menambah 5 hari. Contoh, jika tahun 2018 ini awal Ramadhan jatuh pada Selasa, dengan menambah 5 hari, maka 1 Ramadhan di tahun 2019 kemungkinan besar akan dimulai hari Sabtu.

Metode penetuan 1 Ramadhan di Bungong Keumang telah dikaji dari perspektif astronomi matematis, sehingga hasil kajian itu sudah bisa ditebak bahwa metode 'urfi khumasi sudah ketinggalan, dan kurang relevan untuk kondisi sekarang. Uniknya, masyarakat masih tetap saja memilih 1 Ramadhan dengan metode yang mereka yakini tersebut. Hal ini menunjukkan bahwa penentuan kapan mulai berpuasa bukan hanya persoalan astronomi, tetapi juga persoalan keyakinan (belief), dan social trust kepada pemimpin agama. Ketika seseorang merasa yakin, maka mereka akan melaksanakan, dan mereka tidak peduli bagaimana proses perhitungannya.

Pertanyaan yang akan dijawab dalam tulisan ini adalah mengapa masyarakat lebih memilih mengikuti ketentuan 1 Ramadhan dari pemimpin agama yang kurang tepat dari pada Pemerintah, yang di dalamnya berkumpul para ahli di bidang ilmu astronomi dan juga ahli agama? Untuk menjawab pertanyaan tersebut, penulis menggunakan pendekatan sosiologis, karena praktek pelaksanaan hukum Islam itu bukan semata-mata pertimbangan astronomis matematis, tetapi juga pertimbangan sosial dan keyakinan. Masyarakat awam tidak banyak yang terbiasa dengan keputusan mandiri, tetapi lebih mempertimbangkan pemimpin agama, dan relasi sosial di sekitarnya.

${ }^{3}$ Tgk. Said Jamalul Hakim, sapaan akrab beliau abu (sebutan untuk ulama, atau orang yang dituakan). Beliau merupakan cucu dari Abu Habib Muda Seunagan. "Wawancara” (Nagan Raya: MPU Nagan Raya, 26 Januari 2017).

${ }^{4}$ Hisab ini hanya dilakukan dengan cara penambahan, pengurangan, perkalian, dan pembagian tanpa mempergunakan Ilmu ukur segitiga bola. 
Meminjam teori Bourdieu, bahwa penentuan 1 Ramadhan bisa dikategorikan sebagai 'social field' tempat para aktor berjuang untuk memperoleh kapital. ${ }^{5}$ Hukum Islam yang bersumber dari al-Qur'an dan Hadis untuk mengatur perbuatan manusia juga menjadi wilayah fuqaha dan ahli agama. Di wilayah ini, tokoh agama akan berjuang agar bisa menguasainya. Sebagai 'field', pemimpin agama memiliki peran yang besar bagaimana keputusan 1 Ramadhan itu bisa diterima oleh jama'ah sebagai doxa ${ }^{6}$ yang taken for granted, tanpa harus banyak mempertanyakan atau mengajukan pandangan. Di arena 1 Ramadhan itulah ditemukan pertukaran nilai antara pihak pemimpin agama dan jama'ah. Keduanya terlibat dalam wilayah penentuan 1 Ramadhan.

\section{Relasi Mursyid - Jama'ah sebagai Patronase}

Sekilas Desa Bungong Keumang tidak jauh berbeda dengan desa yang lain di wilayah Aceh. Alam pedesaan dengan hamparan lahan pertanian yang luas menggambarkan bahwa desa ini merupakan desa yang subur, sehingga para petani yang sebagian besar didominasi orang tua memperoleh kemakmuran. Di Desa Bungong Keumang ini awalnya mursyid Habib Muda bermukim dan mendakwahkan ajaran Islam kepada masyarakat luas. Beliau menjadikan Desa Bungong Keumang sebagai pusat kegiatan sosial keagamaanya. Dari desa ini pula, Habib Muda mempertahankan dan mengisi kemerdekaan Indonesia. ${ }^{7}$

Abu Habib Muda dikenal luas di masyarakat sebagai ulama dan pejuang. Masyarakat mengenalnya sebagai ulama yang ikut memimpin perlawanan terhadap penjajah Belanda dan Jepang pada masa penjajahan. Beliau juga sangat gigih mempertahankan keutuhan Negara Kesatuan Republik Indonesia, misalnya beliau tidak setuju dengan pemberontakan DI/TII. Oleh karena itu, beliau menjalin hubungan dengan Ir. Soekarno. Beliau juga tokoh agama dan masyarakat yang berkiprah hingga awal Orde Baru. Keluarga dan masyarakat tidak mengetahui tanggal kelahiran ulama yang dikenal dengan panggilan Abu. Beberapa penulis memperkirakan beliau lahir pada 1860. Beliau wafat pada

${ }^{5}$ Richard Jenkins, Pierre Bourdieu (London: Routledge, 1992), 52, https://books.google.co.id/ books/about/Pierre_Bourdieu.html?id=URxm9ww2p5IC\&redir_esc=y.

6Pierre Bourdieu, Outline of a Theory of Practice - Pierre Bourdieu - Google Buku (Cambridge: Cambridge University Press, 1977), 166.

7Ihsan, Abu Habib Muda Seuagan Republiken Sejati dari Aceh, 7. 
14 Juni 1972. Masyarakat Nagan Raya meyakini bahwa usia Abu Habib Muda mencapai 1 abad. ${ }^{8}$ Untuk mengenang jasa dan meninggalnya, setiap tahun diselenggarakan haul di Desa Bungong Keumang. Jama'ah dari berbagai daerah mendatangi masjid raya di Bungong Keumang ini dengan membawa makanan, dan panitia juga menyiapkannya. Jumlah jama'ah yang hadir sangat besar. Mereka datang dari berbagai daerah. Mereka meyakini bahwa Abu Habib Muda merupakan 'orang sakti' di zamannya. Kesaktian tersebut sebagian masyarakat sekarang masih mempercayainya.

Zentgraaff, penulis berkebangsaan Belanda yang menulis tentang perang Aceh mengatakan, pada 1917 perang antara pasukan Belanda dengan pejuang di Aceh Barat meletus yang dipimpin oleh Tengku Puteh. Tengku Puteh yang disebut Zentgraaff ini tak lain adalah Habib Muda Seunagan. Dengan demikian usia Habib Muda pada 1917 adalah usia yang sangat matang menjadi pemimpin peperangan. ${ }^{9}$

Literatur lain menyebutkan bahwa Abu Habib Muda dilahirkan kira-kira pada tahun 1860 M di Desa Krueng Kulu, Blang Ara Kecamatan Seunagan Timur, Kabupaten Nagan Raya. Beliau anak ke-4 dari 14 bersaudara, 10 orang laki-laki dan 4 orang perempuan. Keluarga tidak mengetahui persis tentang hari, tanggal dan bulan. Hal tersebut sudah umum terjadi pada orang-orang tua zaman dahulu yang tidak ingat persis kapan anaknya lahir. ${ }^{10}$ Pada umumnya orang tua hanya ingat musim apa anaknya itu lahir.

Abu Habib Muda yang nama aslinya Habib Muhammad Yeddin bin Habib Muhammad Yasin bin Habib Abdurrahim Qutubul Ujud bin Habib Abdul Qadir Rama'any bin Said Athaf. Habib Muda diyakini memiliki hubungan silsilah hingga kepada Rasulullah. ${ }^{11}$ Orang tuanya adalah Habib Syaikhuna Muhammad Yasin bin Habib Syaikhuna Abdurahim Qutubul Wujud bin Habib Abdul Qadir Ramani bin Habib Syaikhuna Sayed Ataf. Nama terakhir diyakini memiliki hubungan silsilah Syaikh Abdul Qadir al-Jailani yang juga memiliki silsilah hingga Rasulullah.

8Ihsan, 22.

9Ihsan, 23.

10Sammina Daud, Abu Habib Muda Seunagan Thariqat Syattariyah (Jakarta: Karya Sukses Sentosa, 2008), 26.

11Daud, 27. 
Kondisi Aceh pada waktu itu dalam keadaan perang melawan Belanda. Hal tersebut menjadikan masa kecil Habib Muda berpindah-pindah. Ia pernah dibawa pindah ke daerah Tadu Aceh oleh orang tuanya. Di daerah ini terdapat sebuah sungai dengan sebuah tuwi yang dikenal dengan nama tuwi tomat. Di tempat ini pernah terjadi perang dengan Belanda yang menyebabkan ibu kandung Habib Muda, menjadi syahid. ${ }^{12}$

Abu Habib Muda, setelah mempelajari ilmu syar'i dari ayahnya kemudian beliau dididik ilmu tarekat, yakni jalan atau petunjuk di dalam melaksanakan suatu ibadah sebagaimana telah dicontohkan Rasulullah. Berkat ketekunan dan cintanya beliau kepada ilmu, akhirnya beliau menjadi mursyid Thariqat Syattariyah. ${ }^{13}$ Abu Habib Muda, seorang ulama mazhab Syafi'i pengikut paham Ahlussunnah wal Jama'ah, penyebar Thariqat Syattariyah, sebagai mursyid guru di Aceh Barat dan Aceh Selatan, bahkan seluruh Aceh yang memiliki murid pada tahun 1971 puluhan ribu orang. ${ }^{14}$

Beliau hidup zuhud, wara' dan istiqāmah, disertai dengan pandangan sufi yang tengah dalam menghadapi dan memecahkan masalah. Beliau juga hidup dengan cara yang disiplin. Beliau mendapatkan bimbingan dari seorang ulama Habib Syaikhuna Muhammad Yasin sebagai guru dan ayah kandungnya sendiri untuk menyebarkan sebuah thariqat, yang terbentuk berkat inspirasi seorang alim dari India Syeikh Abdullah as-Syattari.15

Beliau seorang mursyid yang sangat disegani oleh jama'ah, bahkan beliau bukan hanya disegani karena ilmunya, tetapi juga karena kesaktiannya. Menurut jama'ah bahwa pada waktu jama'ah menanyakan 'kenapa belum pernah melihat bulan kok sudah mulai berpuasa', maka tiba-tiba dari mulut Abu Habib keluar cahaya seperti bulan'. Kesaktian Abu Habib ini dipercaya oleh masyarakat, khususnya jama'ah thariqat.

Jama'ah Thariqat Syattariyah ini rata-rata berusia 40 tahun ke atas, dan anak muda jarang yang tertarik dengan kelompok keagamaan ini. Dalam pengajian sering dinyatakan bahwa 'ketika usia sudah tua, apa yang dicari,

\footnotetext{
12Ihsan, Abu Habib Muda Seuagan Republiken Sejati dari Aceh, 24.

13Daud, Abu Habib Muda Seunagan Thariqat Syattariyah, 29.

${ }^{14}$ Daud, 186.

15Daud, 187.
} 
lebih baik fokus pada ibadah untuk bekal ke akhirat'. Untuk menjadi anggota jama'ah Thariqat Syattariyah ini tidaklah mudah, karena mereka harus berpuasa beberapa kali. Pada saat sekarang, anak muda di Desa Bungong Keumang dan sekitarnya sedang tertarik dengan thariqat Naqsabandiyah, yang belum lama didirikan oleh keluarga Abu Habib Muda. Menurut anak muda yang ikut jama'ah thariqat ini bahwa thariqat ini tidak terlalu sulit untuk diikuti oleh anak muda zaman sekarang.

Disparitas antara mursyid dengan jama'ah dalam dunia thariqat sangat lebar. Jama'ah seolah-olah tidak diperkenankan untuk mempertanyakan agama, karena mereka bisa dianggap su'ul adab kepada guru. Jama'ah itu tinggal melaksanakan, bukan mempertanyakan, karena agama itu bukan dipertanyakan tetapi dilaksanakan. Jama'ah harus patuh kepada perintah mursyid, maka baiat menjadi persyaratan menjadi anggota. Di depan mursyid, jama'ah hanya bisa menyatakan 'sami'nā wa ața'nā'. Para pemimpin agama menggali hukum, sedangkan jama’ah tinggal melaksanakan.

Melihat ketidakseimbangan status sosial jama'ah dan mursyid tersebut merupakan syarat terjadinya hubungan patronase, karena berpatron itu penting mempertahankan hidup. Scott juga memberikan penjelasan tentang ciri-ciri tertentu tentang hubungan patronase yaitu teradapat ketidaksamaan (inequality), adanya sifat tatap muka (face to face character) dan sifatnya yang luwes dan meluas (diffuse flexibility). ${ }^{16}$ Adanya ketimpangan (inequality) terjadi karena patron memiliki jasa atau barang yang lebih, sementara klien tidak punya. Agar klien itu bisa bertahan hidup, nyaman dan tenang dalam hidup, maka apa yang berikan patron itu menjadi sesuatu yang sangat berharga. Pihak klien merasa harus membalas apa yang telah diberikan oleh patron. Sesuatu yang berharga itu bisa berupa barang, tetapi juga bisa jasa.

Pada hari Rabu, tanggal 14 Juni 1972 Abu Habib Muda meninggal dunia. Masyarakat Bungong Keumang merasa kehilangan. Abu Habib Muda bukan hanya meninggalkan istri, anak dan keluarga, tetapi meninggalkan juga ratusan anak ideologis dan ribuan pengikutnya. Jama'ah thariqat sangat kehilangan mursyid yang selama ini menjadi panutan. Wasiat dan pesan-pesannya, bukan hanya diingat, melainkan menjadi dasar mereka dalam melakukan interaksi

\footnotetext{
16James C. Scott, "Patron-Client Politics and Political Change in Southeast Asia," American Political Science Review 66, no. 1 (1972): 93, https://doi.org/10.2307/1959280.
} 
sosial, politik, dan keagamaan. ${ }^{17}$ Kelompok keagamaan thariqat yang telah dibentuknya kemudian diteruskan oleh keturunan Abu Habib Muda.

Interaksi mursyid dan jama'ah sangat dibutuhkan untuk melangsungkan kegiatan thariqat. Maka segala aktifitas keagamaan keduanya selalu hadir untuk pertukaran jasa. Hal ini sudah berlangsung lama di dalam kehidupan sehari-hari, maka seolah-olah sudah menjadi norma sosial. Hubungan antara pemimpin agama dan jama'ah ini bukanlah hubungan biasa, tetapi hubungan yang saling membutuhkan, dan ketergantungan dalam rangka mengembangkan kelompok thariqat. Hubungan itu dalam istilah ilmu sosial disebut dengan patronase.

James C. Scott telah memberikan gambaran mengenai hubungan patronase bahwa:

"... a special case of dyadic (two person) ties, involving a largely instrumental friendship in which an individual of higher socio economic status (patron) uses his own influence and resources to provide protection or benefits or both, for a person of a lower status (client) who for his part reciprocates by offering general support and assistance, including personal services, to the patron."18

Istilah 'patron' berasal dari bahasa Spanyol yang secara etimologis berarti 'seseorang yang memiliki kekuasaan (power), status, wewenang dan pengaruh'. Sedangkan klien berarti 'bawahan' atau orang yang diperintah dan yang disuruh. Selanjutnya, pola hubungan patron-klien merupakan aliansi dari dua kelompok komunitas atau individu yang tidak sederajat, baik dari segi status, kekuasaan, maupun penghasilan, sehingga menempatkan klien dalam kedudukan yang lebih rendah (inferior), dan patron dalam kedudukan yang lebih tinggi (superior). Atau, dapat pula diartikan bahwa patron adalah orang yang berada dalam posisi untuk membantu klien-kliennya. ${ }^{19}$

Bentuk hubungan kekuasaan yang terjalin antara tokoh masyarakat (patron) dan klien menjadi suatu norma yang nantinya sebagai kekuatan moral tersendiri dimana didalamnya berisi hak-hak dan kewajiban yang harus dilaksanakan oleh kedua belah pihak. ${ }^{20}$ Hubungan patronase itu merupakan

\footnotetext{
17Ihsan, Abu Habib Muda Seuagan Republiken Sejati dari Aceh, 77-79.

${ }^{18}$ Scott, "Patron-Client Politics and Political Change in Southeast Asia," 92.

${ }^{19}$ Scott

20Muhammad Ramli, "Patronase Politik dalam Demokrasi Lokal (Analisis terhadap Terpilihnya Hj. Marniwati pada Pemilukades di Desa Jojjolo Kecamatan Bulukumpa Kabupaten Bulukumba)," (Skripsi, Universitas Islam Negeri Alauddin, 2016), 61, http://repositori.uin-alauddin.acid/1679/.
} 
proses sosial. Maka, orang yang memiliki strata tinggi tidak otomatis mampu menggunakan pengaruh, perlindungan, dan keuntungan pada klien. Scott juga memberikan penjelasan tentang ciri-ciri tertentu tentang hubungan patronase yaitu terdapat ketidaksamaan (inequality), adanya sifat tatap muka (face to face character) dan sifatnya yang luwes dan meluas. Adanya ketimpangan terjadi karena patron memiliki jasa atau barang yang lebih, sementara klien tidak punya. Agar klien itu bisa bertahan hidup, nyaman dan tenang dalam hidup, maka apa yang diberikan patron itu menjadi sesuatu yang sangat berharga. Maka pihak klien merasa harus membalas apa yang telah diberikan oleh patron. ${ }^{21}$

Hubungan patron-klien adalah pertukaran hubungan antara kedua peran yang dapat dinyatakan sebagai kasus khusus dari ikatan yang melibatkan persahabatan instrumental dimana seorang individu dengan status sosioekonominya yang lebih tinggi (patron) menggunakan pengaruh dan sumber dayanya untuk menyediakan perlindungan, serta keuntungan-keuntungan bagi seseorang dengan status yang dianggapnya lebih rendah (klien). Klien kemudian membalasnya dengan menawarkan dukungan umum dan bantuan termasuk jasa pribadi kepada patronnya. Sebagai pola pertukaran yang tersebar, jasa dan barang yang dipertukarkan oleh patron dan klien mencerminkan kebutuhan yang timbul dan sumber daya yang dimiliki oleh masing-masing pihak

Sedangkan arus dari klien ke patron, adalah: jasa atau tenaga yang berupa keahlian teknisnya bagi kepentingan patron. Adapun jasa-jasa tersebut berupa jasa pekerjaan dasar/pertanian, jasa tambahan bagi rumah tangga, jasa domestik pribadi, pemberian makanan secara periodik. Bagi klien, unsur kunci yang mempengaruhi tingkat ketergantungan dan penglegitimasiannya kepada patron adalah perbandingan antara jasa yang diberikannya kepada patron dan hasil/jasa yang diterimanya. Makin besar nilai yang diterimanya dari patron dibanding biaya yang harus ia kembalikan, maka makin besar kemungkinannya ia melihat ikatan patron-klien itu menjadi sah dan legal.

\footnotetext{
${ }^{21}$ Agus Nurhadi, "Patronase Kyai Pembimbing KBHI dan Jamaahnya," agusnurhadi2010. wordpress.com, 2011, https://agusnurhadi2010.wordpress.com/2011/09/21/patronase-kyaipembimbing-kbih-dan-jamaahnya/.
} 
Hubungan kekuatan antara patron dan klien menjadi suatu norma yang mempunyai kekuatan moral tersendiri di mana didalamnya berisi hak-hak dan kewajiban yang harus dilaksanakan oleh kedua belah pihak. Norma-norma tersebut akan dipertahankan sejauh memberikan jaminan perlindungan dan keamanan dasar bagi klien. Usaha-usaha untuk merumuskan kembali hubungan tersebut kemudian dianggap sebagai usaha pelanggaran yang mengancam struktur interaksi itu sehingga sebenarnya kaum elit atau patronlah yang selalu berusaha untuk mempertahankan sistem tersebut demi mempertahankan keuntungannya. Hubungan ini berlaku wajar karena pada dasarnya hubungan sosial adalah hubungan antar posisi atau status dimana masingmasing membawa perannya masing-masing. Peran ini ada berdasarkan fungsi masyarakat atau kelompok, ataupun aktor tersebut dalam masyarakat, sehingga apa yang terjadi adalah hubungan antar posisi di keduanya. ${ }^{22}$

\section{Musyawarah Menentukan 1 Ramadhan}

Thariqat Syattariyah di Desa Bungong Keumang menggunakan metode hisab bilangan lima. Meskipun Abu Marsyul Alam, Cucu dari Abu Habib Muda menyatakan "Hisab yang digunakan adalah Hisab Hakiki Taqribi,"23, tetapi bagi ahli falak, metode ini termasuk hisab 'urfi yaitu 'urfi khumasi - menambah bilangan 5 untuk menentukan tahun berikutnya. Metode Hisab 'urfi khumasi termasuk hisab yang sudah lama tidak digunakan, karena metode ini kurang relevan dengan perhitungan astronomis. Namun, di Bungong Keumang hisab ini masih dijadikan patokan dalam penentuan awal bulan. Terutama dalam penentuan Ramadhan, Maulid, dan Idul Adha. Apabila dalam penentuan 1 Ramadhan jatuh pada hari Kamis, maka dapat diperkirakan Maulid dan Idul Adha akan jatuh pada hari Kamis. Mereka tidak terlalu rumit untuk menghitungnya. Metode ini tetap dipertahankan karena ini warisan dari mursyid Abu Habib yang telah lama dilaksanakan di masyarakat dalam menentukan awal Ramadhan.

Namun demikian, masyarakat awam Bungong Keumang pada umumnya tidak mengetahui bagaimana sistem hitungan hisab tersebut. Masyarakat

\footnotetext{
${ }^{22}$ Adi Prasetijo, "Hubungan Patron Klien," Etnobudayanet, 2008, https://etnobudayanet/ 2008/07/31/hubungan-patron-klien/.

${ }^{23}$ Abu Marsyul Alam, cucu Abu Habib Muda Seunagan, Ketua masjid Bungong Keumang, "Wawancara" (23 Agustus 2017).
} 
hanya mengikuti keputusan yang telah ditetapkan oleh para ulama Thariqat Syattariyah. Sebelum menentukan masuknya awal bulan, majelis akan bermusyawarah. Masyarakat mengakui sebagai orang awam tinggal mengikuti perintah pemimpin. Hubungan orang awam dengan pemimpin itu berprinsip 'sami'nā wa ața'nā (mendengarkan dan mengikuti) yang diperintahkan para pemimpin agama.

Abu Marsyul Alam selaku ketua dalam majelis selalu mengatakan bahwa penentuan awal Ramadhan akan dimusyawarahkan 15 hari sebelum puasa yakni sekitar tanggal 15 Syaban. Memulai awal Ramadhan selalu tergantung pada keputusan majelis. Musyawarah Majelis dihadiri oleh setiap khalifah (kelompok thariqat) dari Desa Bungong Keumang dan sekitarnya, dan dilakukan di masjid Jami' Habib Muda Seunagan. Beberapa khalifah bermusyawarah untuk memberikan pendapatnya masing-masing tentang hisab yang telah mereka hitung. Keputusan diambil berdasarkan keputusan majelis. ${ }^{24}$ Cara ini ini sudah menjadi tradisi yang diwariskan sejak awal oleh Abu Habib Muda, sehingga generasi sekarang ini tinggal meneruskan. Mereka tidak berani melakukan perubahan, karena hal ini merupakan warisan nenek moyang yang sangat dicintai.

Di Bungong Keumang, perbedaan dalam memulai ibadah puasa Ramadhan sudah biasa terjadi dari tahun ke tahun. Perbedaan penentuan awal Ramadhan masyarakat Bungong Keumang dengan Pemerintah, diantaranya disebabkan oleh metode yang digunakan, sikap taqlìd masyarakat kepada pemuka kaom, umur bulan selalu 30 hari, dan dua hari yang tidak diperbolehkan berpuasa yaitu hari Rabu dan Jumat. Data yang penulis temukan sejak tahun 2012, menggambarkan perbedaan awal bulan Ramadhan dan Syawal antara Bungong Keumang dengan Pemerintah.

Tebel 1 menunjukkan bahwa hampir setiap tahun terjadi perbedaan penentuan 1 Ramadhan dan 1 Syawal antara masyarakat Bungong Keumang dengan Pemerintah. Hal tersebut sebenarnya telah berlangsung puluhan tahun, sejak era penjajahan hingga sekarang ini. Perbedaan itu secara perhitungan astronomis matematis tidaklah wajar, karena perbedaannya terlalu

\footnotetext{
${ }^{24}$ Asih Pertiwi, "Metode Penentuan Awal Akhir Ramadan Menurut Tarekat Syattariyah di Desa Peuleukung Kecamatan Seunagan Timur Kabupaten Nagan Raya Aceh" (Skripi, Universitas Islam Negeri Walisongo, Juni 22,2017), http://eprints.walisongo.ac.id/7788/.
} 
jauh (2-3 hari), dan terjadi hampir setiap tahun. Namun, bagi masyarakat Bungong Keumang sendiri, hal itu sudah biasa. Mereka tidak peduli dengan metode perhitunganya -apakah tepat atau tidak. Bagi masyarakat Bungong Keumang, mereka mematuhi keputusan dari pemimpin agama yang diwakili oleh majelis thariqat. Mereka meyakini dan melaksanakan apa yang telah ditanamkan semenjak Abu Habib Muda Seunagan hidup hingga sekarang. Mereka lebih percaya penentuan dari majelis thariqat daripada perhitungan Pemerintah.

Di Desa Bungong Keumang, perbedaan diantara kedua metode tersebut sudah lumrah adanya, karena hampir setiap tahun terjadi. Menurut ketua Masjid Bungong Keumang Tgk. Marsyul Alam "Penentuan awal bulan Ramadhan di Bungong Keumang menggunakan Sistem Hisabiyah”. 25

Hisab menurut bahasa berarti hitungan, sedangkan menurut istilah hisab adalah perhitungan benda-benda langit untuk mengetahui kedudukannya pada satu saat yang diinginkan. ${ }^{26}$ Jadi, apabila seseorang ingin mengetahui kedudukan benda-benda langit, maka metode hisab sangat membantu untuk mengetahui letak benda langit.

Tabel 1.

Perbedaan Awal Bulan Ramadhan dan Syawal antara Bungong Keumang dengan Pemerintah

\begin{tabular}{lllll}
\hline \multirow{2}{*}{ Tahun M/H } & \multicolumn{2}{c}{ Bungong Keumang } & \multicolumn{2}{c}{ Pemerintah } \\
\cline { 2 - 5 } & 1 Ramadhan & 1 Syawal & 1 Ramadhan & \multirow{2}{*}{ 1 Syawal } \\
\hline $2012 / 1433$ & Kamis 19 Juli & Sabtu 18 Agustus & Sabtu 21 Juli & Senin 20 Agustus \\
$2013 / 1434$ & Senin 8 Juli & Rabu 7 Agustus & Rabu 10 Juli & Jumat 9 Agustus \\
$2014 / 1435$ & Sabtu 28 Juni & Minggu 27 Juli & Minggu 29 Juni & Selasa 29 Juli \\
$2015 / 1436$ & Selasa 16 Juni & Kamis 16 Juli & Kamis 18 Juni & Jumat 17 Juli \\
$2016 / 1437$ & Sabtu 4 Juni & Senin 4 Juli & Senin 6 Juni & Rabu 6 Juli \\
$2017 / 1438$ & Kamis 25 Mei & Sabtu 24 Juni & Sabtu 27 Mei & Ahad 25 Juni \\
\hline
\end{tabular}

Sumber: data diolah penulis dari berbagai sumber

Menurut Ilmu Falak, hisab yang digunakan untuk menentukan awal Ramadhan di Bungong Keumang menggunakan hisab 'urfi khumasi yaitu

25Abu Marsyul Alam, "Wawancara," 23 Agustus 2017.

26Maskufa, Ilmu Falak, Jakarta: Gaung Persada Press, 2010.h. 147-148. 
dengan penambahan 5 hari dari tahun sebelumnya. Hitungan hisab ini sekarang sangat jarang digunakan.

Abu Marsyul Alam selaku ketua dalam majelis selalu mengatakan bahwa penentuan awal Ramadhan dimusyawarahkan 15 hari sebelum puasa yakni sekitar tanggal 15 Sya'ban. Memulai awal Ramadhan selalu tergantung pada keputusan majelis. Setiap khalifah dari beberapa wilayah tarekat ini berkumpul untuk menentukan kapan jatuhnya 1 Ramadhan. Ulama yang berkumpul membahas penentuan tersebut berdasarkan masing-masing hisab yang mereka yakini. ${ }^{27}$ Pada saat majelis dibuka, perwakilan ulama yang diundang berhak memberikan argumen hasil hitungan mereka. Setelah itu mereka bermusyawarah menentukan hari yang akan menjadi awal Ramadhan. Namun, dalam penentuan awal Ramadhan sangatlah berbeda dengan sistem hisab yang lain. Karena ada 2 hari yang tidak diperbolehkan untuk memulai puasa, yaitu hari Rabu dan hari Jumat. Semua tokoh masyarakat masih memegang teguh hal ini, karena pengecualian hari itu sudah ada semenjak Abu Habib Muda hidup. Tgk. Said Azman selaku kepala dinas Pendidikan Nagan Raya menyatakan "Tidak boleh memulai berpuasa pada hari Rabu dan Jumat". Sama halnya dengan Tgk. Said Jamalul Hakim menjabat sebagai Kepala MPU (Majelis Permusyawaratan Ulama) Nagan Raya "Tidak boleh memulai puasa pada hari Rabu karena itu adalah hari sakit-makit 28 , juga pada hari Jumat karena hari itu merupakan hari raya umat Islam."

Tgk. Maksin ${ }^{29}$ selaku pemegang kendali Makam Abu Habib Muda menyatakan "Ada satu hari lagi yang diyakini tidak boleh memulai puasa Ramadhan, yaitu hari Ahad". Namun hal ini tidak dibenarkan oleh Tgk. Marsyul Alam karena alasan tidak diperbolehkan berpuasa pada hari Ahad sangat lemah. Pengecualian hari tersebut memunculkan perbedaan yang sangat jauh dengan Pemerintah. Karena dalam penambahan 5 hari dengan hari pada tahun sebelumnya, memberikan loncatan yang jauh. Kebiasaan dalam me-

\footnotetext{
27Pertiwi, "Metode Penentuan Awal Akhir Ramadan."

${ }^{28}$ Sakit-makit, hari yang diyakini penduduk Bungong Keumang banyak terjadi bencana, serangan penyakit, dan segala sesuatu yang berhubungan dengan malapetaka, maka tidak diperbolehkan memulai puasa pada hari Rabu.

${ }^{29}$ Tgk Maksin juru kunci makam Abu Habib Muda Seunagan, "Wawancara” (Bungong Keumang, 23 Agustus 2017).
} 
nentukan 1 Ramadhan sudah bertahun-tahun berjalan sehingga hal itu sulit dileburkan.

Pada saat pengumpulan data, penulis mendapatkan bukti musyawarah pemuka kaom Bungong Keumang yang dicatat oleh Tgk. Marsyul Alam. Namun, pencatatan hanya dimulai dari tahun 2014 sampai tahun 2017. Karena kesadaran dari Tgk. Marsyul Alam sendiri untuk mencatat penetapan 1 Ramadhan di Bungong Keumang. Berikut penulis paparkan hasil penetapan 1 Ramadhan oleh para pemuka kaom yang hadir pada saat musyawarah penetapan 1 Ramadhan di Bungong Keumang.

Gambar 1 menunjukkan hasil musyawarah yang sudah disimpulkan oleh takmir masjid Bungong Keumang Tgk. Marsyul Alam pada tahun 2014. Ada 6 orang yang menghadiri musyawarah tersebut. Proses kegiatan seperti musyawarah biasa, tidak ada perhitungan yang rumit, tidak banyak perdebatan tentang dasar hukum. Musyawarah memutuskan bahwa pada tahun 2014, awal puasa berbeda dengan penentuan Pemerintah. Hasil dari perhitungan di Desa Bungong Keumang, 1 Ramadhan 1435 H hari Jum'at, namun karena dalam penetapan 1 Ramadhan di Bungong Keumang tidak diperbolehkan memulai puasa pada hari Jumat, maka puasa dimundurkan menjadi hari Sabtu. Berbeda dengan Pemerintah yang memulai 1 Ramadhan 1435 H pada hari Minggu.

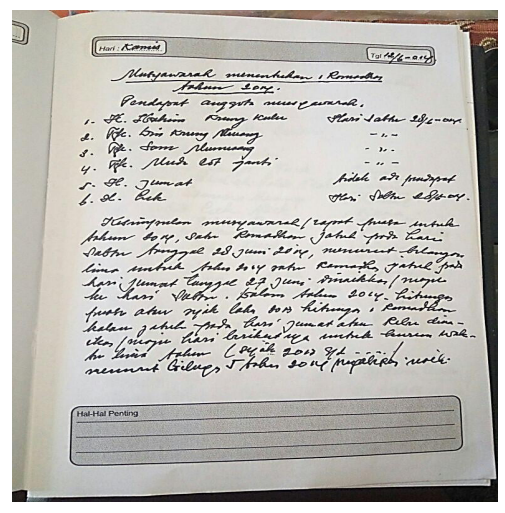

Gambar1.

Penetapan 1 Ramadhan tahun 2014 
Pada tahun 2015, musyawarah di Bungong Keumang oleh 13 pemuka kaom. Hasil musyawarah penetapan 1 Ramadhan $1436 \mathrm{H}$ jatuh pada hari Selasa. Sedangkan penetapan 1 Ramadhan oleh Pemerintah jatuh pada hari Kamis. Perbedaan kembali terjadi dalam penetapan 1 Ramadhan antara Bungong Keumang dengan Pemerintah, tahun 2015 perbedaan terjadi hingga 2 hari.

Penetapan 1 Ramadhan pada tahun 2016 di Bungong Keumang dihadiri oleh 15 orang, terjadi peningkatan para pemuka kaom yang menghadiri musyawarah dari tahun sebelumnya. 1 Ramadhan $1437 \mathrm{H}$ di Bungong Keumang jatuh pada hari Sabtu, sedangkan ketetapan Pemerintah dalam penetapan 1 Ramadhan 1437 H jatuh pada hari Senin. Dalam penetapan ini kembali terjadi perbedaan hingga 2 hari

Pada tahun 2017 perbedaan terjadi antara Pemerintah dan Bungong Keumang. Musyawarah yang dihadiri oleh 27 orang pemuka kaom (pemuka agama) Bungong Keumang, lebih meningkat dari tahun-tahun sebelumnya. Penetapan 1 Ramadhan 1438 H jatuh pada hari Kamis di Bungong Keumang. Sedangkan ketetapan Pemerintah penentuan 1 Ramadhan 1438 H jatuh pada hari Sabtu. Maka kembali terjadi perbedaan hingga 2 hari antara Bungong Keumang dan Pemerintah.

Data di atas menunujkan bahwa hisab menentukan 1 Ramadhan itu tidak rumit seperti hitungan astronomis, tetapi berbasis pada musyawarah para pemuka agama. Catatan dari musyawarah hanya daftar hadir, pendapat dan kesimpulan. Mereka berasal dari para khalifah Thariqat Syattariyah yang ada di Bungong Keumang dan sekitarnya. Yang perlu dipertimbangkan hanya usia bulan 30 hari, penambahan 5, dan larangan untuk memulai berpuasa (Rabu dan Jum'at).

\section{Dukungan Jama'ah}

Di dalam hubungan patronase bidang sosial keagamaan, penentuan kapan jatuhnya hari raya keagamaan itu sangat penting. Pemimpin agama yang mampu mengelola hari raya keagamaan akan memperoleh social trust dari masyarakat luas. Maka bisa dipahami bahwa setiap ormas memiliki metode atau cara untuk mengelola wilayah hukum Islam seperti menentukan 1 Ramadhan ini sebagai 'field' - arena yang menghasilkan kapital yang dibutuh- 
kan di dalam kehidupan sosial ini. Apalagi awal Ramadhan itu memiliki hubungan dengan 1 Syawal yang merupakan salah satu hari raya keagamaan terbesar di kalangan umat Islam.

Dalam teori sosial, hubungan patronase terjadi ketika ada pertukaran barang dan jasa antara patron dan klien, yang saling mereka butuhkan. Para elit agama itu membutuhkan dukungan dari jama'ah, sebaliknya jama'ah membutuhkan sesuatu yang bisa diperoleh dari pemimpin agama. Dukungan dari jama'ah ini yang bisa diberikan secara riil kepada elit agama. Dukungan itu nilai yang sangat berharga bagi para elit agama. Semakin banyak jama'ah, maka semakin tinggi dukungan kepada elit agama. Maka kecenderungan yang terjadi bahwa kelompok keagamaan berusaha meningkatkan jumlah jama'ah untuk memperbesar dukungan.

Meskipun hanya dukungan, tetapi hal tersebut sangat penting bagi elit agama. Dukungan itu diperlukan bagi elit agama. Pertama, nama besar semakin banyak dukungan, maka nama juga semakin besar. Orang tidak hanya butuh jenang, tetapi juga butuh jeneng. Dalam falsafah Jawa disebutkan bahwa 'golekko jeneng, mengko bakal enthuk jenang' (carilah nama baik, nanti bakal dapat materi). Kalau orang itu memiliki nama baik, maka berarti pintu yang lain juga mulai dibuka. Baik jalan dakwah, pendidikan, kebutuhan materi dan sebagainya.

Kedua, kepentingan dakwah. Semakin besar dukungan, semakin mudah melakukan dakwah. Ormas keagamaan akan sangat mempertimbangkan aspek dakwah ini. Visi dan missi dari thariqat juga bisa disampaikan (tabligh) kepada masyarakat luas. Agama memerintahkan untuk amar ma'rüf nahī munkar, memberikan nasihat, dan berdakwah. Maka setiap ormas keagamaan pasti memiliki misi dakwah ini. Islam bisa dikenal luas seperti sekarang ini karena ada kegiatan dakwah. Maka pada hari-hari tertentu, jama'ah dari Thariqat Sattariyah ini berkumpul agar syiar dari agama itu tampak di masyarakat.

Ketiga, mempermudah proses edukasi kepada masyarakat, terutama pendidikan agama. Edukasi dan pemberdayaan masyarakat untuk agama terus dilakukan, sebagai bekal hidup di dunia dan akhirat. Semakin besar pengikut thariqat ini, maka semakin mudah mursyid menyampaikan pesan kepada masyarakat luas. Edukasi masyarakat akan mudah dilakukan kalau ada dukungan dari masyarakat. 
Keempat, semakin tinggi political bargaining. Semua pemimpin politik butuh dukungan politik, baik pada waktu proses pemilihan maupun implementasi kebijakan. Apakah kemudian ini bisa disebut politisasi agama? Jangan terburu-buru untuk menghakimi. Politik itu sarana agar nilai dan moral itu mudah diimplementasikan di masyarakat. Tujuan politik yang sebenarnya itu bukan untukjabatan, tetapi melaksanakan nilai-nilai moral keIslaman.

Mengingat pentinganya dukungan dari jama'ah itu, maka dukungan itu harus dikelola agar potensial menjadi sarana dakwah, edukasi dan political bargaining. Ada beberapa cara untuk mengelola dukungan jama'ah. Pertama, baiat kepada anggota jama'ah. Baiat ini mungkin dianggap aneh, tetapi dalam dunia thariqat, hal ini sudah biasa dilakukan. Ini merupakan bagian dari manajemen sumber daya manusia. Baiat merupakan bentuk kesetiaan jama'ah kepada pemimpin agama. Untuk bisa dibaiat tidak mudah. Mereka harus memenuhi persyaratan, di antaranya berpuasa 3 hari, puasa 7 hari, berpuasa 14 hari, dan terakhir berpuasa 40 hari. Cara berpuasa juga diatur, misalnya makan hanya sedikit, air putih sedikit, jangka waktu juga agak lama. Bahkan jika ketentuan puasa itu gagal, karena tidak kuat, maka mereka harus mengulang dari awal pada tahun berikutnya. Hal itu dilakukan agar jama'ah itu memiliki jiwa prihatin yang tinggi, hidup sederhana. Baiat juga bermakna ikatan keanggotaan. Maka siapa yang telah dibaiat, mereka terikat dengan aturan yang dibuat oleh pemimpin agama.

Kedua, memperkuat identitas. Orang lain akan mengatakan dengan istilah political identity. Penentuan 1 Syawal tidak mau kompromi dengan ahli falak, meskipun kurang tepat. Hari raya keagamaan itu menjadi penting untuk mengetahui identitasi anggota. Semakin besar kuantitasnya, maka semakin diperhitungkan. Pada saat hari raya, mereka datang dari berbagai daerah, menunaikan shalat idul fitri atau idul adha. Pada waktu era Tengku Zulkarnain menjabat sebagai bupati, shalat idul fitri sampai meluber halaman dan jalan raya. Orang dari luar daerah berdatangan, bahkan menginap di sekitar Bungong Keumang ini agar bisa menunaikan shalat Idul Fitri. Seberapa besar dukungan yang diberikan jama'ah akan terlihat pada saat jama'ah itu berkumpul. Kuantitas jumlah jama'ah pada saat berkumpul menjadi ukuran yang terlihat dukungan kepada pemimpin agama. Oleh karena itu, pemimpin agama pada hari keagamaan akan mengumpulkan jama'ah, baik dalam bentuk peringatan hari raya keagamaan, acara haul atau acara lain. 
Ketiga, memperkuat solidaritas. Dalam bahasa Durkheim, masyarakat akan kuat kalau memiliki solidaritas yang tinggi, demikian juga sebaliknya. Masyarakat yang tidak memiliki solidaritas sangat berbahaya, karena solidaritas merupakan kebutuhan sosial. Masyarakat yang solidaritasnya rendah disebut anomi - mengalami kekacauan. Oleh karena itu, untuk memperkuat solidaritas, mereka saling berkumpul, saling membantu satu sama lain. Hal ini diperlukan untuk pengelolaan jama'ah. Mereka menganggap bahwa ikut thariqat ini bermanfaat untuk kehidupan di dunia dan akhirat. Oleh karena itu, thariqat yang didirikan oleh Abu Habib Muda ini berusaha untuk memperkuat solidaritas sesama anggota, dengan cara berkumpul, saling membantu, memberi makanan. Solidaritas sesama anggota thariqat merupakan social capital yang penting untuk mempertahankan lembaga thariqatnya. Setiap malam Sabtu, anggota jama'ah juga berkumpul untuk pengajian, berdzikir, dan kegiatan lain yang berkaitan dengan jama'ah thariqat. Dengan berinteraksi degan jama'ah akan memperkuat solidatiras, dan mengatasi persoalan yang dihadapi jama'ah.

Namun demikian, seiring perubahan sosial, dukungan yang diberikan kepada pemimpin agama dari Bungong Keumang ini sedang mengalami penurunan. Dengan teknologi media sosial, masyarakat semakin terbuka dan bebas untuk mengakses informasi tentang penentuan 1 Ramadhan. Mereka juga semakin rasional di dalam memilih, tidak bisa dikapling-kapling dan diarahkan oleh pemimpin agama, dan ketergantungan kepada pemimpin agama juga semakin berkurang, karena mereka bisa belajar dengan internet. Keturunan dari Abu Habib juga tidak terpilih lagi menjadi Bupati Nagan Raya, sehingga relasi kuasa dengan pejabat dengan jama'ah juga semakin berkurang. Akibatnya jumlah jama'ah yang hadir pada saat lebaran Idul Fitri ataupun Idul Adha juga berkurang.

\section{Kebutuhan Jama'ah}

Dalam perspektif masyarakat Bungong Keumang, mereka hanya mengikuti keputusan mursyid atau imam tarekat dalam penentuan awal Ramadhan. Setelah melakukan kajian, penulis menyimpulkan bahwa hampir seluruh masyarakat Bungong Keumang tidak mengetahui bagaimana metode penentuan awal Ramadhan. Mereka menyerahkan seutuhnya pada keputusan akhir dari hasil musyawarah para ulama yang hadir dalam majelis. Taat 
kepada ulil amri masih dipegang teguh oleh masyarakat di desa tersebut, sebagaimana firman Allah dalam surah al-Nisā' ayat 59: 'Taatilah Allah dan taatilah Rasul (Muhammad) dan ulil amri (pemegang kekuasaan) di antara kamu. ${ }^{30}$ Ulil amri dipahami sebagai pemegang kekuasaan bidang agama - yaitu para ulama. Penentuan 1 Ramadhan itu wilayah ulama, maka mereka lebih mematuhi ulama daripada Pemerintah.

Menurut Darmin ${ }^{31}$ selaku masyarakat setempat "Keputusan penentuan awal Ramadhan yang selalu berbeda dengan Pemerintah itu dikembalikan kepada imam, karena sebagai pengikut kami belum mempunyai ilmu tentang itu dan itu menjadi tanggung jawab imam tersebut" sebagai pengikut mereka hanya patuh kepada imam mereka dalam menentukan awal bulan Ramadhan. Karena dangkalnya ilmu para pengikut, sehingga mereka tidak ingin sembarangan dalam memulai puasa.

Pemimpin mempunyai wewenang untuk memutuskan, dan masyarakat mempunyai hak untuk menjalankan keputusan tersebut. Keduanya memiliki hubungan timbal balik, tidak dapat dipisahkan satu sama lain, pemimpin tidak bisa hidup tanpa adanya masyarakat yang dipimpin, begitu pula masyarakat tidak bisa melakukan hal seenaknya tanpa arahan dari pemimpin. Dalam kasus masyarakat Desa Bungong Keumang ini hubungan patronase antara pemimpin dan masyarakat sangat erat. Dibuktikan dengan adanya kepatuhan masyarakat mengikuti perintah dari pemimpin kaom tersebut, khususnya dalam melaksanakan awal Ramadhan.

Hubungan antara kepentingan tokoh dan masyarakat Bungong Keumang bisa dilihat dari berbagai hal. Pertama, masyarakat adalah orang awam yang tidak mengetahui ilmu untuk menentukan 1 Ramadhan, sehingga masyarakat hanya taqlïd dengan putusan yang diberikan oleh para pemimpin kaom. Hukum mempelajari Ilmu Falak adalah fardu kifāyah. Apabila ada beberapa orang yang mengetahui ilmu tersebut, maka penduduk desa tersebut tidak perlu ikut dalam menentukan 1 Ramadhan. Akan tetapi, sebaiknya dalam musyawarah penentuan 1 Ramadhan ada beberapa pemuda atau pemudi yang diikutsertakan, karena mereka adalah calon penerus ajaran Thariqat Syattariyah di Bungong Keumang.

${ }^{30}$ QS. al-Nisā’: 59.

31Darmin, masyarakat Nagan Raya, "Wawancara” (24 Agustus 2017). 
Kedua, adanya hubungan timbal balik antara tokoh masyarakat dan masyarakat Bungong Keumang. Hal itu karena yang memutuskan 1 Ramadhan adalah tokoh masyarakat dan yang menjalankan putusan adalah masyarakat. Apabila masyarakat tidak melaksanakan putusan yang sudah ditetapkan, maka fungsi dari tokoh masyarakat tidak dapat terealisasikan. Karena hubungan antara tokoh masyarakat (patron) dan masyarakat (klien) adalah saling menguntungkan satu sama lain. Tokoh masyarakat sebagai pemutus, sudah melaksanakan tugasnya, dan masyarakat sebagai pelaksana harus melaksanakan tugasnya - menjalankan putusan pemimpin kaom mereka. Di Desa Bungong Keumang, pemimpin agama itu sekaligus pemimpin thariqat, yang memiliki karakter pemimpin kharismatik, jama'ah tinggal menjalankan apa yang diperintahkan. Hasil kajian Max Weber menyatakan bahwa charismatic leaders telah lama berkembang dalam sejarah, dan sangat dipatuhi oleh pengikutnya, bahkan sampai pada tingkat dominasi. ${ }^{32}$ Maka putusan 1 Ramadhan pasti akan dipatuhi oleh jama'ah.

Masyarakat Bungong Keumang hanya taqlìd kepada para pemimpin mereka. Mereka termasuk orang yang awam, dan belum paham ilmu untuk menetapkan awal bulan Ramadhan. Karena keterbatasan itulah, mereka hanya menunggu hasil keputusan syura. Tetapi ada baiknya, bagi masyarakat yang mengikuti ajaran tersebut untuk mendalami bagaimana metode perhitungan atau ikut andil dalam syura. Karena dikhawatirkan, apabila di masa yang akan datang tidak ada lagi penerus yang akan melanjutkan ajaran dalam Thariqat Syattariyah tersebut. Melihat yang ikut serta dalam syura adalah para sesepuh kaum dan para tokoh yang sudah lanjut usia.

Dengan prinsip sami'na wa ața'nā kepada mursyid, maka jama'ah akan memperoleh apa yang dibutuhkannya. Mursyid memberikan fatwa, jama'ah tinggal mengikutinya. Mursyid menggali hukum dengan pengetahuannya, jama'ah tinggal melaksanakan hukum tersebut. Ini merupakan perintah agama. Dalam al-Qur'an dinyatakan bahwa orang yang beriman diperintahkan untuk taat kepada Allah, kemudian kepada rasul dan kepada ulil amri. Makna uli amri menurut masyarakat Bungong Keumang itu para pemimpin agama. Maka, keputusan 1 Ramadhan termasuk yang harus ditaati.

32Talcott Parsons, From Max Weber: Essays in Sociology, ed. H. H. Gerth and C. Wright Mills (New York: Oxford University Press, 1947), 250. 
Kepatuhan mereka terlihat jelas dengan selalu mengikuti hasil keputusan musyawarah pemimpin mereka dalam menetapkan 1 Ramadhan. Padahal, di atas pemimpin mereka ada yang lebih harus ditaati yaitu Pemerintah. Masyarakat melupakan peran Pemerintah, sebagai pemegang kekuasaan penuh dalam memutuskan 1 Ramadhan dalam wilayat al-hukmi Indonesia. Ini yang sekarang menjadi perbincangan dari kalangan ahli agama dan ahli astronomi, yang sampai sekarang masih menjadi khilafiah (perbedaan pendapat).

Hal ini bisa dimaklumi, karena kurangnya turun tangan Pemerintah dalam mensosialisasikan hal tersebut. Masyarakat, selaku orang awam tidak mengerti hal tersebut. Mereka hanya mengikuti keputusan yang sudah diserahkan kepada pemimpin kaom. Dalam hal ini masyarakat tidak dapat disalahkan, karena hanya tunduk dengan keputusan yang sudah ditetapkan, berbeda apabila para masyarakat mempunyai penentuan lain dengan pemimpin kaom. Apabila hal tersebut terjadi, maka perlu ada peninjauan lanjutan. Namun, hal itu tidak terjadi, maka Pemerintah hanya perlu mensosialisasikan hal tersebut kepada para pemimpin kaom yang nantinya akan disebarluaskan kepada masyarakat Bungong Keumang.

Lalu apa kebutuhan dari jama'ah yang bisa diberikan oleh pemimpin agama? Patronasi merupakan hubungan pertukaran barang atau jasa. Kebutuhan jama'ah itu bisa diberi oleh pemimpin agama, meskipun tidak semua bisa dipenuhi. Pertama, keberkahan hidup. Hidup berkah itu dicari banyak orang. Masyarakat di Desa Bungong Keumang menginginkan hidup itu berkah. Berkah ini memiliki pengertian yang luas. Tidak kaya, tetapi hartanya cukup untuk memenuhi kebutuhan hidup. hidupnya bermanfaat bagi banyak orang. Anaknya tidak nakal, dan patuh pada orang tua. Hal-hal di atas merupakan ukuran berkah. Keluarga Abu Habib Muda dan keturunannya menjadi idola, karena hidupnya bukan hanya memberi manfaat kepada dirinya, tetapi juga masyarakat dan sekitarnya.

Kedua, membantu doa. Dalam pikiran orang awam, mereka itu kotor, doa sulit terkabul dan sebagainya, maka agar mudah dikabulkan, mereka meminta mursyid untuk mendoakan. Kebutuhan hajatan dari jama'ah itu banyak variasinya. Semua berharap agar jalannya hajatan itu lancar, maka mereka minta bantuan kepada mursyid untuk mendoakan. Kalau anaknya mau kuliah atau kerja di luar kota, bangun rumah dan sebagainya, mereka meminta 
mursyid untuk mendoakan. Bisa didoakan oleh mursyid itu kebanggaan jama'ah, karena bukan orang sembarangan yang mendoakan.

Ketiga, konsultan hidup. Jama'ah selalu membutuhkan orang tua yang dianggap memiliki kelebihan. Untuk memberi nama kepada anak agar tidak mudah sakit, tidak nakal, menjadi anak shalih, beragam hajatan mulai sunatan, perkawinan dan sebagainya. Hari baik untuk membuka usaha, hari baik untuk mendirikan rumah dan sebagainya. Jama'ah sebagai orang awam sangat butuh konsultan bagaimana bisa hidup dan bertahan di masyarakat. Hidup di dunia ini tantangannya tidak mudah, maka jama'ah membutuhkan pihak orang lain yang dianggap bisa menjadi konsultan dalam hidupnya. Pilihannya jatuh kepada pemimpin agama. Mungkin orang lain akan menganggap tidak rasional, tetapi ini realitas masyarakat di Bungong Keumang. Jama'ah akan merasa lebih tenang, sehingga tidak salah di dalam hidupnya.

Tampaknya hubungan patronase di Bungong Keumang ini berjalan mulus, tidak pernah terdengar protes, menolak keputusan dan sebagainya. Heddy Shri Ahimsa-Putra memberi penjelasan bahwa untuk memuluskan hubungan itu diperlukan beberapa unsur. Pertama, apa yang diberikan itu merupakan sesuatu yang sangat dibutuhkan di dalam hidupnya, dan tidak mudah dipenuhi oleh orang lain. Sehingga pihak penerima merasa berkewajiban untuk membalasnya -seakan berdosa jika tidak membalasnya. Kedua, hubungan itu timbal balik, tidak sepihak. Patron dan klien itu pemberi dan sekaligus sebagai penerima. Patron memberikan sesuatu yang diperlukan oleh klien dan sebaliknya klien memberikan sesuatu yang butuhkan oleh patron. Ketiga, norma di masyarakat mendukungnya. Hubungan patronase akan berjalan baik kalau didukung oleh norma di masyarakat. Misalnya, wong cilik merasa tidak enak kalau tidak membalas jasa orang besar. ${ }^{33}$

Namun demikian, seiring dengan perubahan sosial yang terjadi, proses demokrasi dan kemandirian sosial, kemudahan akses pada informasi, menurunkan social trust kepada pemimpin, sangat dimungkinkan hubungan patronasi itu akan mengalami penurunan. Ketika relasi kuasa semakin berkurang, generasi milenial membutuhkan pilihan yang bervariasi, maka

\footnotetext{
${ }^{33}$ Heddy Shri Ahimsa-Putra, Patron dan Klien di Sulawesi Selatan: Sebuah Kajian Fungsional Struktural (Yogyakarta: Kepel, 2007), 4.
} 
patron akan mengalami diversifikasi, tidak mengumpul pada pemimpin agama saja. Maka berpatron pada Thariqat Syattariyah yang didirikan oleh Abu Habib is not the only way yang ada di Bungong Keumang. Konsekuensinya, patronasi juga akan mengalami pergeseran.

\section{Kesimpulan}

Kajian ini menyimpulkan bahwa masyarakat Desa Bungong Keumang itu lebih memilih mendahului Pemerintah dalam penentuan 1 Ramadhan itu bukan karena persoalan metode 'urfi khumasi yang digunakan, tetapi karena ada hubungan patronasi antara jama'ah dengan pemimpin agama. Jama'ah sebagai klien sangat sami'nā wa ața'nā keputusan pemimpin agama sebagai patron. Majelis yang terdiri dari perwakilan khalifah melakukan musyawarah 15 hari sebelum puasa Ramadhan, jama'ah dan masyarakat pada umumnya hanya melaksanakan keputusan. Mereka hanya melaksanakan perintah pemimpin agama agar hidupnya berkah, bermanfaat sebagaimana telah dialami dalam kehidupan di keluarga mursyid. Jama'ah menjadikan para pemimpin agama itu sebagai konsultan hidup dan sekaligus dimintai bantuan doa agar hidupnya selamat kehidupan dunia dan akhirat. Demikian juga sebaliknya, para pemimpin agama hanya menginginkan dukungan dari jama'ah. Semakin besar dukungan semakin mudah untuk berdakwah, mengedukasi masyarakat, melaksanakan kegiatan sosial, menerapkan nilai moral kepada masyarakat. Pertukaran nilai itu menghasilkan hubungan patronase antara pemimpin agama dan jama'ah. Patronase itu terus dipelihara di dalam kehidupan sosial sehari-hari di masyarakat, seolah menjadi norma kepatutan yang wajib dipatuhi. Pemimpin agama menyadari bahwa wilayah penentuan 1 Ramadhan, yang memiliki konsekuensi hari raya besar keagamaan ini, merupakan 'field of Islamic law' yang menjadi wilayahnya, maka pemimpin agama tidak menyianyiakan kesempatan tersebut untuk menunjukkan kepada masyarakat bahwa elit agama merupakan bagian dari masyarakat. Di dalam 'field of Islamic law' terdapat 'spiritual capital' yang tinggi untuk keberlangsungan kehidupan sosial ini. Namun demikian, seiring dengan berkurangnya ketergantungan klien kepada patron, kemudahan akses informasi yang berkaitan dengan ketentuan 1 Ramadhan, jama'ah yang melaksanakan metode 'urfi khumasi sebagaimana yang dilaksanakan di Desa Bungong Keumang semakin berkurang. Hal ini menegaskan bahwa penentuan hari besar keagamaan bukan murni persoalan 
astronomi, tetapi juga sangat berhubungan dengan aspek sosial dan politik yang melingkupinya.[a]

\section{DAFTAR PUSTAKA}

Ahimsa-Putra, Heddy Shri. Patron dan Klien di Sulawesi Selatan: Sebuah Kajian Fungsional Struktural. Yogyakarta: Kepel, 2007.

Alam, Abu Marsyul. "Wawancara.” 23 Agustus 2017.

Bourdieu, Pierre. Outline of a Theory of Practice - Pierre Bourdieu - Google Buku. Cambridge: Cambridge University Press, 1977.

Darmin. “Wawancara.” 24 Agustus 2017.

Daud, Sammina. Abu Habib Muda Seunagan Thariqat Syattariyah. Jakarta: Karya Sukses Sentosa, 2008.

Hakim, Tgk. Said Jamalul. “Wawancara.” 26 Januari 2017.

Ihsan, Sehat. Abu Habib Muda Seuagan Republiken Sejati dari Aceh. Banda Aceh: Bandar Publishing, 2015.

Jenkins, Richard. Pierre Bourdieu. London: Routledge, 1992.

Maksin, Tgk. “Wawancara.” 23 Agustus 2017.

Nurhadi, Agus. "Patronase Kyai Pembimbing KBHI dan Jama'ahnya." agusnurhadi2010.wordpress.com, 2011. https://agusnurhadi2010. wordpress.com/2011/09/21/patronase-kyai-pembimbing-kbih-danjama'ahnya/.

Parsons, Talcott. From Max Weber: Essays in Sociology. Ed. H. H. Gerth and C. Wright Mills. New York: Oxford University Press, 1947.

Pertiwi, Asih. "Metode Penentuan Awal Akhir Ramadhan Menurut Tarekat Syattariyah di Desa Peuleukung Kecamatan Seunagan Timur Kabupaten Nagan Raya Aceh." Skripsi. Universitas Islam Negeri Walisongo, 2017. http://eprints.walisongo.ac.id/7788/.

Prasetijo, Adi. "Hubungan Patron Klien." Etnobudaya.net, 2008. dalam https://etnobudaya.net/2008/07/31/hubungan-patron-klien/.

Ramli, Muhammad. "Patronase Politik dalam Demokrasi Lokal (Analisis terhadap Terpilihnya Hj. Marniwati pada Pemilukades di Desa Jojjolo Kecamatan Bulukumpa Kabupaten Bulukumba)." Skripsi. Universitas 
Islam Negeri Alauddin Makassar, 2016. http://repositori.uinalauddin.ac.id/1679/.

Scott, James C. "Patron-Client Politics and Political Change in Southeast Asia." American Political Science Review 66, no. 1 (March 1, 1972): 91-113. https://doi.org/10.2307/1959280.

Tim Liputan. "Warga Nagan Mulai Puasa." Harian Rakyat Aceh. Diakses pada 27 Juli 2017. https://harianrakyataceh.com/2017/05/29/warganagan-mulai-puasa/. 
